\title{
Performance of the LandSoil expert-based model to map erosion and sedimentation: application to a cultivated catchment in central Belgium
}

\author{
Vincent Cantreul, ${ }^{1 *}$ (D) Nathalie Pineux, ${ }^{2}$ Gilles Swerts, ${ }^{1}$ Charles Bielders ${ }^{3}$ and Aurore Degré ${ }^{1}$ \\ 1 Gembloux Agro-Bio Tech, Liège University, Gembloux, Belgium \\ 2 Public Service of Wallonia (SPW), Namur, Belgium \\ ${ }^{3}$ Faculty of Bioscience Engineering and Earth and Life Institute, Université catholique de Louvain (UCL), Louvain-La-Neuve, \\ Belgium
}



\begin{abstract}
Intensive agricultural practices on sensitive soils induce high erosion rates in central Belgium. Expert-rules models quantify runoff and erosion at catchment scale, avoiding over-parameterization, and can include some direct or indirect connectivity features. The aim of this article is to test the ability of an expert-based model, LandSoil, to quantify runoff and to locate erosion and sedimentation areas in a small cultivated loamy catchment in Belgium during the years 2014, 2015 and 2016. Spatialized data are important for assessing model outputs and the erosive response. Measurements of runoff and observation of spatial erosion/deposition patterns, especially around major connectivity points, permitted an assessment of the reliability of the model results. Runoff modelling gave contrasting results (good linear adjustment at the outlet of the 83 ha sub-catchment (point 1 ): $r^{2}$ of 0.96, Nash-Sutcliffe criterion of 0.95; less good at the outlet of the 3.9 ha sub-catchment (point 2): $r^{2}$ of 0.28 , Nash-Sutcliffe criterion of -0.47). For point 2 the poor results are explained by the very few runoff events observed, a scaling effect and the small area with a single land use. Graduated rulers demonstrate that the model is able to provide a coherent pattern of erosion/deposition. The study highlights great sensitivity to the effect of land use, land allocation, landscape design and slope gradients. Grass strips induce deposition of eroded particles when slopes are gentle $(<2 \%)$. Woodland strips decrease connectivity by being in the stream but deposit thinner sediment layers. Field boundaries have a role in the transport, but not really the quantity, of sediments. This model validation in the Belgian loess context allows us to use LandSoil in other similar environments in order to estimate the effects of landscape management scenarios. (C) 2020 John Wiley \& Sons, Ltd.
\end{abstract}

KEYWORDS: erosion; connectivity; modelling; expert rules; spatialized data

\section{Introduction}

Soil erosion by water on agricultural fields and subsequent sediment transport has large and varied consequences on the environment and population (Boardman, 1988; Verstraeten and Poesen, 1999; Bielders et al., 2003; Evrard et al., 2007; Fiener et al., 2011). These impacts (e.g. muddy floods, sedimentation of rivers and retention ponds, crop destruction, loss of soil and nutrients) have risen over the last few decades and are expected to worsen in the future (Nearing et al., 2004; Boardman and Vandaele, 2010) especially because of anthropic activities (e.g. increased size of agricultural plots, destruction of linear landscape elements, increased tillage intensity and resulting loss of soil organic matter, climatic changes).

For nearly a century there have been many studies on erosion processes, including detachment, transport and sedimentation, in order to better understand these processes and find appropriate solutions. Erosion-related processes depend on numerous factors, are strongly non-linear and are characterized by large spatial and temporal variability, which makes the study of soil erosion highly complex (Hurst et al., 2012 López-Vicente et al., 2013). Spatial and temporal heterogeneities of rainfalls and soil characteristics are a challenge. Initially, many studies have focused on runoff and erosion at the field scale (Biddoccu et al., 2017). More recently, the catchment scale was preferred because many of the off-site consequences of erosion have to be managed at catchment scale, and because it gives additional information on processes occurring between different fields (Hutton et al., 2014; Pineux et al., 2017a). In particular, it has become apparent that the internal functioning of the catchment, especially connections between different spatial units (e.g. grass strips, field boundaries or roads), plays a crucial role in the understanding of runoff and sediment transfers (Rose et al., 2003; Rodríguez-Blanco et al., 2013; Akram et al., 2014; Navarro-Hevia et al., 2015). It is therefore necessary to better understand phenomena around these specific spots in order to better represent the whole-system behaviour. 
To deal with heterogeneities, the concept of connectivity was introduced at the end of the twentieth century. It identifies erosion processes and tries to understand how they occur to explain water and sediment movements in the catchment (Western et al., 2001; Bracken and Croke, 2007; Baartman et al., 2013). Considering the diversity of definitions of the connectivity concept in the literature, it is important to clearly specify the definition used in this study. Connectivity is here defined as 'the physical linkage of sediment through the system, which is the transfer of sediment from one zone or location to another and the potential for a specific particle to move through the system' (Bracken et al., 2013 page 18). In the catchment, linear landscape elements (e.g. grass strip, wood strip, road, field boundary) change connectivity aspects, showing why this concept can help to better understand runoff and erosion patterns.

Models have improved our understanding of water and sediment transfer in catchments (Evrard et al., 2009; Singh et al., 2011; Da Silva et al., 2013; Boll et al., 2015). Many models have been developed to evaluate management practices. In this framework of runoff and erosion modelling at catchment scale, incorporating water and sediment connectivity is a mean to improve model outputs (Takken et al., 2005; Couturier et al., 2013; Nunes et al., 2018). Various studies have demonstrated the benefits of using models that include connectivity aspects in order to quantify runoff and erosion more accurately (Lesschen et al., 2009; Medeiros et al., 2010; Gumière et al., 2011; López-Vicente et al., 2013; Liu and Fu, 2016). This concept takes heterogeneities into account, which constitutes a key to improving catchment behaviour modelling (López-Vicente et al., 2013). For instance, Smith et al. (2018) demonstrated that models that capture the effects of spatial and temporal variations in agricultural and conservation practices on soil erosion and sediment delivery greatly improve the model outcome and facilitate decision making regarding catchment management practices. The difficulty lies in integrating connectivity into models without over-parameterization (Heckmann et al., 2014), because highly parameterized models have operational limitations (Blöschl and Sivapalan, 1995; Lane, Nichols and Paige, 1995; Seyfried and Wilcox, 1995).

Among the different types of models, expert-based models try to represent erosion in the catchment by considering only the dominant erosion processes for a specific situation in order to prevent over-parameterization (Cerdan et al., 2002b; Evrard et al., 2009; Paroissien et al., 2015). They allow quantification of runoff and sediment flows following rules defined by experts. STREAM and LandSoil are examples of expert-based models. Using limited inputs, including the digital elevation model (DEM), field boundaries, infiltration capacity, imbibition rainfall and potential sediment concentration, it permits the quantification of runoff and sediment production in a spatially distributed way in the catchment. LandSoil includes some connectivity features to model runoff and erosion directly (e.g. through topography, field boundaries or grass strips) or indirectly (e.g. through soil surface characteristics).

LandSoil (and its predecessor STREAM) has been used in several studies in Western Europe in the past few years. More specifically, the model has been used to model interrill erosion in different environments, analyse the impact of erosion on agricultural landscape evolution, model the impact of land-use change and rainfall seasonality on sediment export, assess soil redistribution in a hedgerow landscape and model ephemeral gully erosion (Cerdan et al., 2002a; Souchère et al., 2003; Evrard et al., 2009; Ciampalini et al., 2012; Lacoste et al., 2014). As for most modelling efforts, the validity of the LandSoil model has so far been mostly tested against data recorded at the catchment outlet or for a limited number of locations where water and sediment fluxes are monitored within catchments. However, as highlighted by various authors, a correct mass balance at the catchment scale does not necessarily imply a correct representation of the spatial patterns of erosion and deposition (Takken et al., 1999; Jetten et al., 2003). There is a need for spatialized data to test modelling results (Pineux et al., 2017a). The objective of the present study was therefore to evaluate the capacity of the LandSoil model to quantify runoff, but mostly to represent erosion and deposition patterns in two nested catchments between 2014 and 2016, and more specifically to investigate the effect of linear landscape elements.

\section{Materials and Methods}

\section{Study area}

The study area is an experimental catchment located in the town of Chastre (Figure 1) in the middle of the Belgian loess
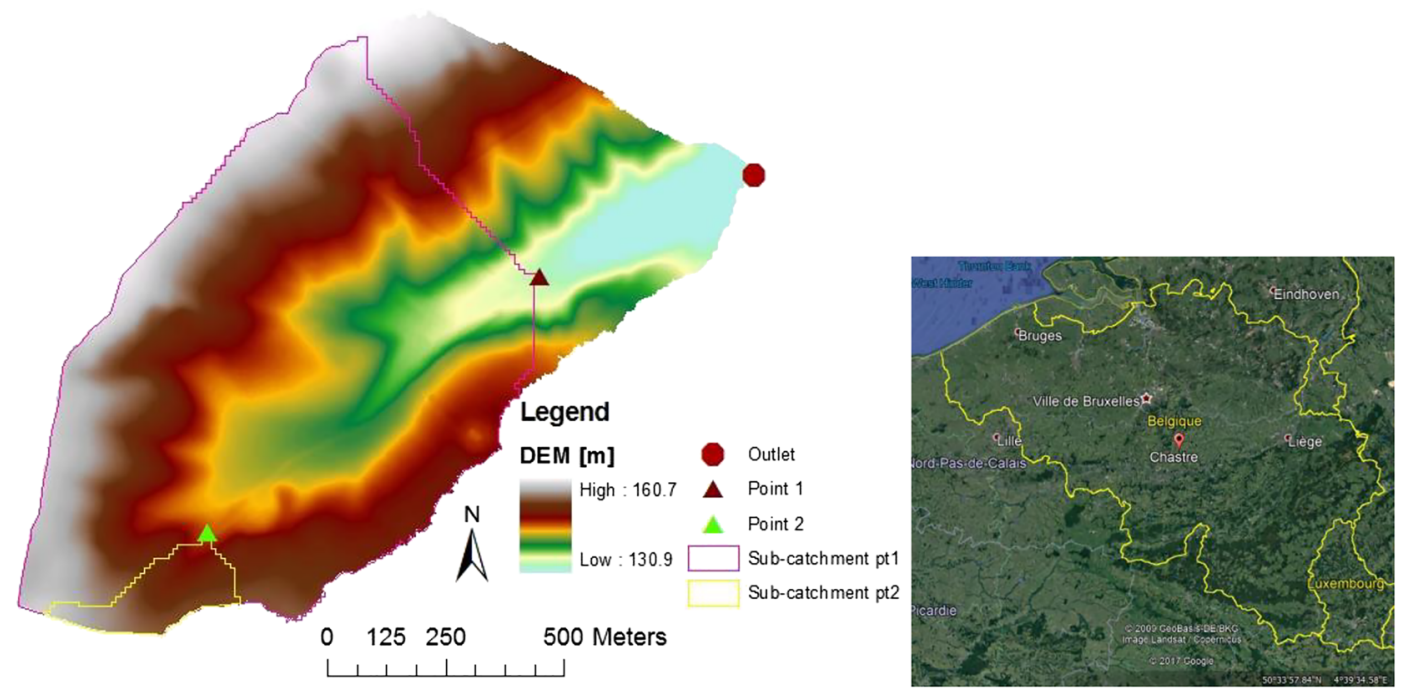

Figure 1. Presentation of the study area [location, digital elevation model (DEM), measurement points and outlet]. [Colour figure can be viewed at wileyonlinelibrary.com] 
belt $\left(50^{\circ} 36^{\prime} 23.02^{\prime \prime} \mathrm{N}, 4^{\circ} 35^{\prime} 42.33^{\prime \prime} \mathrm{E}\right)$. The Belgian loess belt is known for high rates of soil erosion by water and frequent muddy floods (Verstraeten and Poesen, 1999; Bielders et al., 2003; Verstraeten et al., 2006; Boardman and Vandaele, 2010; Boardman, 2010; Evrard et al., 2007, 2010). The 124 ha catchment is described in detail in Pineux et al. (2017b) and Cantreul et al. (2018). Subcatchment 1 has a size of 84 ha and subcatchment 2 is 3.9 ha. Predominant soils are Cambisols and Luvisols, all derived from quaternary loess, which are very sensitive to diffuse and concentrated erosion (Evrard et al., 2008). Land use is more than 95\% agricultural. Cultivation is conventional in the area, based on mouldboard ploughing to a depth of 25 to $30 \mathrm{~cm}$, except for a small field downstream where no tillage is practiced (Cantreul et al., 2018). Main crop rotations are composed of wheat, potato, sugar beet, barley, corn and flax (Figure 2). The remaining $5 \%$ of land is composed of grass strips and a woodland strip; linear landscape elements which are the main focus of the present study. Grass strips were present until November 2014 and then removed. The woodland strip is composed of mixed tree species (broadleaf and coniferous trees) from 2 to $5 \mathrm{~m}$ high. Undergrowth is composed of grass or bushes where the tree density is lower (less than $5 \%$ of the strip). Annual average precipitation reaches $826 \mathrm{~mm} \mathrm{yr}^{-1}$. Elevation ranges between 128 and $161 \mathrm{~m}$ and the slope gradient ranges between 0 and 15\%, 4\% on average (Cantreul et al., 2018). There are two measurement points (points 1 and 2 on Figure 1) in the catchment, situated along the main flow axis for discharge measurements with a flume and a flowmeter. A weather station is located close to point 1 with a tipping bucket rain gauge and a disdrometer with a one-minute time step. A disdrometer measures the rainfall amount and intensity but it underestimates rainfall amount, especially for rainfall intensities higher than $20 \mathrm{~mm} \mathrm{~h}^{-1}$ (Liu et al., 2013). Rain gauge measurements were used for rainfall amounts and the disdrometer for rainfall intensity.

\section{LandSoil model}

LandSoil is a spatially-distributed model based on the STREAM erosion (Souchère et al., 1998, 2003; Cerdan et al., 2002a, $2002 \mathrm{~b}$ ) and the WaTEM/SEDEM tillage erosion model (Govers et al., 1994). STREAM models runoff and erosion at plot or small catchment spatial scales and at rainfall event timescales. It is adapted as an ArcGis template which provides ready-touse layouts to make the interface easy to understand. The objective with LandSoil is to analyse topographic evolution in an agricultural landscape resulting from soil redistribution in the catchment (Ciampalini et al., 2012). After each rainfall or ploughing event, a new DEM is calculated taking into account all eroded or deposited soil transported in the runoff water flow.

\section{Model inputs}

The basic idea of LandSoil is that soil surface characteristics are the major factors that influence runoff generation and erosion processes in small cultivated catchments (Cerdan et al., 2002b). For a few decades, the scientific community has worked on soil surface characteristics which are important for runoff and erosion purposes (Boiffin, 1986; Govers et al., 1990; Le Bissonnais et al., 2005). These characteristics are soil roughness (both parallel and perpendicular to the main slope direction), soil surface crusting and vegetation cover. For each month and crop, the four properties are quantified in categories. The model therefore relies on spatially distributed information in order to include catchment processes linked to hydrological connectivity. The main properties are taken into account as follows (Cerdan et al., 2002b):

- Soil roughness: -1 : not indicated, 0: 0-1 cm, 1: 1-2 cm, 2: $2-5 \mathrm{~cm}, 3: 5-10 \mathrm{~cm}, 4: 10-15 \mathrm{~cm}, 5:>15 \mathrm{~cm}$. It represents the difference in height between the deepest part of microdepressions and the lowest point of their divide.
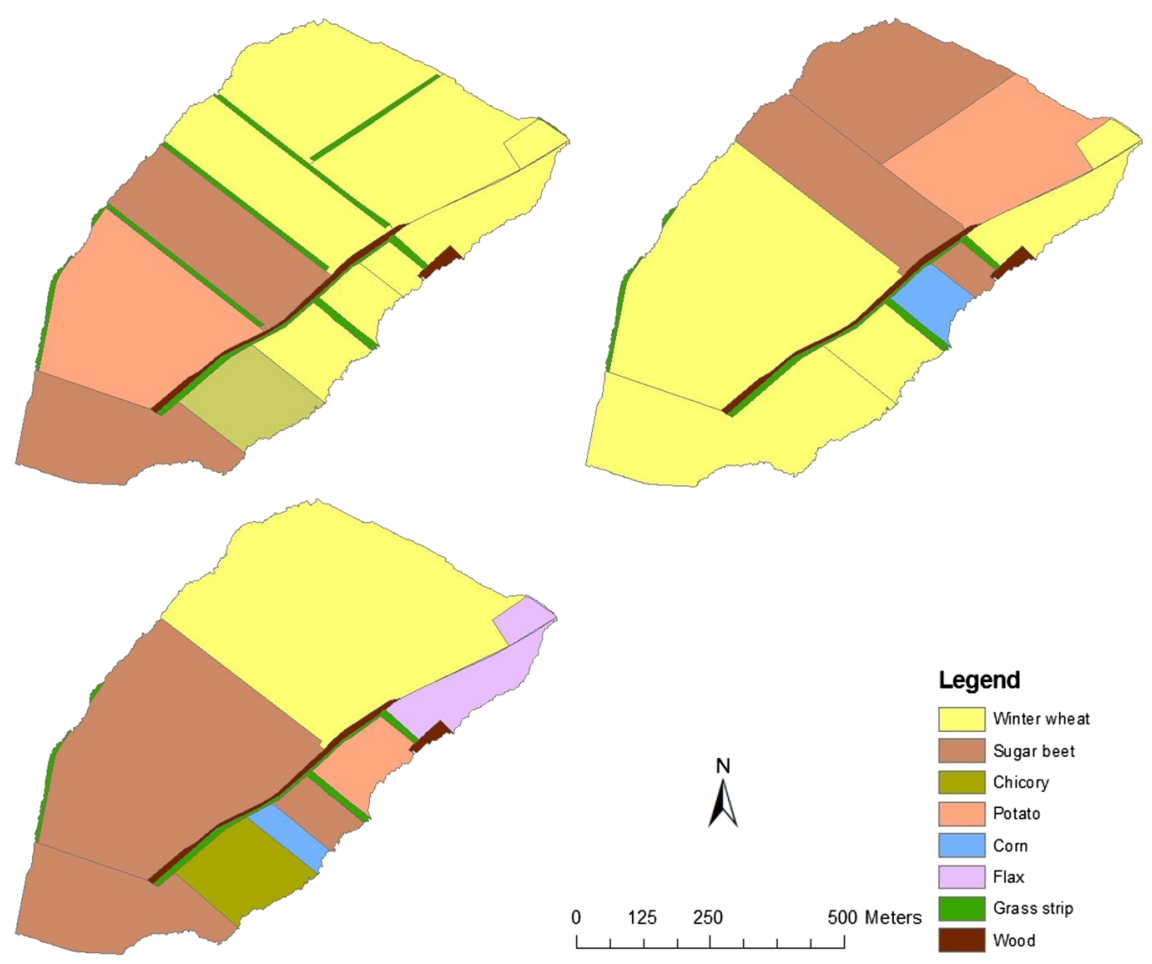

Figure 2. Field allocation for 2014, 2015 and 2016. [Colour figure can be viewed at wileyonlinelibrary.com] 
- Soil surface crusting: -1 : not indicated, 0 : initial fragmentary stage, 11: first stage of degradation/structural crusts, 12: structural crust with local presence of sedimentary crust, 2 : general sedimentary stage. The physical meaning of the levels of soil surface crusting comes from Boiffin (1986) and Bresson and Boiffin (1990) who established a classification system for surface crusts formed by rainfall in loamy soils.

- Vegetation cover: -1: not indicated, 1: 0-20\%, 2: 21-60\%, 3: $61-100 \%$.

LandSoil also requires a DEM, land use, field boundaries (dead furrow, head land, road or ordinary boundary) and rainfall characteristics (duration, quantity, intensity, 48 hours antecedent rainfall).

Model operation

A detailed description of the LandSoil model is available in Souchère et al. (1998, 2003) and Cerdan et al. (2002a, 2002b).

Runoff calculation. For each combination of vegetation cover, soil roughness and soil surface crusting, a steady-state soil infiltration capacity is assigned following an expert rule. For central Belgium, Evrard et al. (2009) adapted the original rule from Le Bissonnais et al. (1998, 2005). However, lower sand content in this study catchment compared to the catchments studied by Evrard et al. (2009) might lead to significant differences in infiltration capacity [20\% sand for Evrard et al. (2009), 5\% for Chastre catchment]. This was confirmed by preliminary measurements (unpublished). For this reason, a new field measurement campaign was carried out in June 2018 and June 2019 using a Decagon ${ }^{\circledR}$ Mini Disk portable tension infiltrometer. Eighteen combinations of vegetation cover, soil roughness and soil surface crusting were measured, and 11 others were extrapolated by comparison between Evrard et al.'s (2009) expert rule and our measurements.

By incorporating the 48 hour-antecedent rainfall, an imbibition rainfall value is assigned for each combination of infiltration capacity and 48 hour-antecedent rainfall. It represents the rainfall quantity required to saturate the soil before runoff (Cerdan et al., 2002b).

Afterwards, an infiltration/runoff balance is calculated as:

$$
B=T-W-l * t
$$

where $B$ is the infiltration/runoff balance (in millimetres), $T$ is the total rainfall event amount (in millimetres), $W$ the imbibition rainfall (in millimetres), I the steady-state soil infiltration rate (in $\mathrm{mm} \mathrm{h}^{-1}$ ) and $t$ the rainfall event duration (in hours).

The runoff routing is calculated for each pixel of the catchment using a modified single-flow algorithm (Souchère et al., 1998). It permits runoff to follow the main linear direction, such as tillage direction or a ditch for instance, rather than follow the steepest downslope. The choice of routing along a topographic path flow or ploughing direction is determined by the threshold effect based on soil surface roughness (Ciampalini et al., 2012).

Erosion calculation. The erosion types considered in the model are water erosion (rill, interrill and ephemeral gully) and tillage erosion (Ciampalini et al., 2012).

Several studies have highlighted the importance of ephemeral gully erosion in central Belgium (Vandaele and Poesen, 1995; Maugnard et al., 2014). In the model, rill and gully erosion are calculated using an empirical relationship developed by Souchère et al. (2003). An ephemeral gully occurs when overland flow discharge exceeds critical shear strength for gully initiation. The module operation works as follows:
- Evaluation of flow discharge depending on:

Slope factor. Depending on the slope percentage, a factor is assigned between 1 and 4; 4 being the highest slope.

O Friction factor. This is calculated using soil roughness, vegetation cover and land use. It varies between 1 and 5, the highest value corresponding to low friction.

- Evaluation of the shear strength:

$\bigcirc$ Cohesion factor. Following land use, vegetation cover and soil surface crusting (the first two take into account the effect of root density and compaction of subsurface soil layers), a factor is assigned between 1 and 5; 5 having the lowest resistance to gully initiation.

- Sensitivity to gully erosion $=$ runoff volume $\times$ slope factor $\times$ friction factor $\times$ cohesion factor.

- Assignment of a rill/gully section (values from observed rill sections) depending on the calculated sensitivity to gully erosion.

Interrill erosion occurs when particles eroded by splash are remobilized by runoff on hillslopes. LandSoil models this process with an expert rule, assigning a potential sediment concentration to the runoff water for each combination of vegetation cover, soil roughness, soil crusting and rainfall intensity on the field plot (Cerdan et al., 2002a). Potential sediment concentrations were adapted for central Belgium by Evrard et al. (2009) based on five years of measurements of vegetation cover, soil roughness, soil crusting, rainfall characteristics and sediment concentration in the runoff.

Deposition occurs when sediment load in the flow exceeds its transport capacity (Cerdan et al., 2002a). The reduction of the transport capacity is calculated using different threshold functions, taking into account changes in topography (vertical curvature, slope gradient), increase in infiltration rate and increase in vegetation cover. A maximum sediment concentration derived from field measurements (Cerdan et al., 2002a), both for rill/gully and interrill erosion, is applied. Topographic characteristics inducing deposition are slope gradient $<2 \%$ and vertical curvature $>0.055$. Vegetation induces deposition if vegetation cover $>60 \%$. When reaching these thresholds, sediments are deposited with a concentration in excess of $10 \mathrm{gl}^{-1}$. Regarding grass strips, the literature (Van Dijk et al., 1996; Lecomte, 1999; Deletic and Fletcher, 2006) has reported sediment concentrations after strips below $2 \mathrm{gl}^{-1}$. The threshold value was set to $5 \mathrm{gl}^{-1}$ above which sediments are deposited (Cerdan et al., 2002a).

Tillage erosion is identified as the most important process leading to redistribution of the soil in agricultural landscapes (Govers et al., 1994) such as the Belgian loess belt. It depends on soil properties, landscape characteristics and the tillage implements used (Van Muysen et al., 2000). LandSoil calculates a flow direction only taking DEM into account. After that, a tillage model is applied that modifies runoff directions and is derived from rules based on field observations or resulting from statistical analysis (Souchère et al., 1998). Dead furrows or tillage are linear landscape elements that modify flow direction. Aspect, derived from the DEM, is combined with tillage direction to obtain the slope angle. Then, a discriminant function based on slope angle and slope intensity is used to choose the cell following topography or tillage. In addition, roughness determination in each plot decides whether the discriminant function is to be applied or if tillage direction is used directly (Souchère et al., 1998).

To convert erosion mass to erosion depth, one single value of bulk density can be defined in LandSoil. Based on measurements on cultivated soils in the Belgian loam belt (Kader 
et al., 2010), a mean value of $1.3 \mathrm{~g} \mathrm{~cm}^{-3}$ was used. This value is also used for deposition height calculations.

Implementation of connectivity features. Connectivity features existing in the catchment during the study period were grass strips, a woodland strip and field boundaries. For runoff and erosion calculations, strips behave like any other plot with soil surface properties determining water and sediment amounts. Field boundaries (dead furrow, headland, road or ordinary limit) introduce anthropic factors to the flow direction model. The choice between slope and tillage or headland direction represents the first anthropic level. A discriminant function applies when parallel and perpendicular roughness varies by two classes or more. Dead furrows and roads constitute the second anthropic level, adding some preferential flows. For dead furrow the flow direction is the direction of the furrow, but for roads it keeps the slope direction and assigns an infiltration capacity of zero (Souchère et al., 1998, 2003; Cerdan et al., 2002a, 2002b).

Model outputs

For runoff, LandSoil builds different spatially distributed maps which provide information on infiltration and runoff catchment behaviours during a rainfall event [e.g. imbibition rainfall (in millimetres), saturated infiltration capacity (in $\mathrm{mm} \mathrm{h}^{-1}$ ), infiltration/runoff balance (in millimetres) or runoff accumulation (in $\mathrm{m}^{3}$ )]. Table I summarizes all these outputs.

For sediments, the model provides map results for different processes: diffuse erosion, linear erosion, tillage erosion, total erosion, deposition and topography modification (Table I).

\section{Data}

Digital elevation model (DEM)

The DEM used in this study was constructed from LiDAR (light detection and ranging) acquisitions from the Service Public de Wallonie, Belgium. The flights covered the whole region between 12 December 2012 and 9 March 2014 (Figure 1). The resolution is $1 \mathrm{~m}$, this was previously shown to be the best resolution for sediment connectivity studies in the central Belgium context (Cantreul et al., 2018). The planimetric precision is less than $1 \mathrm{~m}$, and absolute altimetric precision is $0.12 \mathrm{~m}$. All details about flight parameters, methods used to process the point cloud or corrections to the gross DEM are described in the LiDAR DEM production report (Région Wallonne, 2015).

Adapted soil surface properties and expert rules

The soil surface properties were observed monthly in the catchment for each crop. They were supplemented by observations made close by in the Belgian loess belt (Evrard et al., 2008). The different classes are provided in Table II. Table III presents the technical itinerary for all crops.

Table IV presents saturated infiltration capacity for all combinations of soil properties observed between 2014 and 2016 in the catchment. The combinations observed during June 2018 and June 2019 (time of the Mini Disk measurements) are in red, representing the mean of five different measurement locations. The other values needed for LandSoil (in green) were deduced by comparisons between red values and the corresponding values from Evrard et al. (2009). The infiltration capacity, governed by soil surface characteristics, is one of the most sensitive inputs in the LandSoil model (Ciampalini et al., 2017). Observed values taken during the field campaign were smaller than those from Evrard et al. (2009). One limitation of the measurements with the Mini Disk is that the saturated hydraulic conductivity is estimated by extrapolation of 
Table III. Technical itinerary for all crops during the measurement period

\begin{tabular}{|c|c|c|c|c|c|c|}
\hline & April & May & June & July & August & September \\
\hline $\begin{array}{l}\text { Winter } \\
\text { wheat }\end{array}$ & & & & Harvesting & Plowing & \\
\hline $\begin{array}{l}\text { Sugar } \\
\text { beet }\end{array}$ & Seeding & & & & & \\
\hline Chicory & Seeding & & & & & \\
\hline Potato & Ridging & Seeding & & & & Harvesting \\
\hline Corn & Seeding & & & & & \\
\hline Flax & Seeding & & & & Harvesting & \\
\hline $\begin{array}{c}\text { Mustard } \\
\text { cover }\end{array}$ & & & & & & \\
\hline crop & & & & & Seeding & \\
\hline
\end{tabular}

Table IV. Saturated infiltration capacities $\left(\mathrm{mm} \mathrm{h}^{-1}\right)$ for each combination of soil surface properties in the catchment of Chastre

\begin{tabular}{|c|c|c|c|c|c|}
\hline \multirow[b]{2}{*}{$\begin{array}{l}\text { Roughness } \\
\text { (cm) }\end{array}$} & \multicolumn{5}{|c|}{ Soil surface crusting (-) } \\
\hline & $\begin{array}{c}\text { Vegetal } \\
\text { cover } \\
(\%)\end{array}$ & Fo & F11 & F12 & F2 \\
\hline \multirow[t]{3}{*}{ R5 } & C3 & 75 & & & \\
\hline & C2 & & & & \\
\hline & C1 & & & & \\
\hline \multirow[t]{3}{*}{ R4 } & C3 & & 75 & & \\
\hline & C2 & $74(35.0)$ & & & \\
\hline & $\mathrm{C} 1$ & 50 & & & \\
\hline \multirow[t]{3}{*}{ R3 } & $\mathrm{C} 3$ & & & $25(28.2)$ & \\
\hline & C2 & & 18 & & \\
\hline & C1 & 25 & 18 & 15 & \\
\hline \multirow[t]{3}{*}{ R2 } & C3 & & & $18(3.2)$ & \\
\hline & C2 & & 18 & $12(3.0)$ & \\
\hline & C1 & 18 & 10 & $9(1.4)$ & $6(2.5)$ \\
\hline \multirow[t]{3}{*}{ R1 } & C3 & & 18 & $15(1.9)$ & $10(4.4)$ \\
\hline & $\mathrm{C} 2$ & & $14(4.1)$ & $11(0.4)$ & \\
\hline & $\mathrm{C} 1$ & 15 & $8(2.2)$ & $6(1.2)$ & $6(2.1)$ \\
\hline \multirow[t]{3}{*}{ R0 } & C3 & & 10 & $10(2.6)$ & $4(1.0)$ \\
\hline & C2 & & $8(2.4)$ & $5(2.0)$ & $4(1.6)$ \\
\hline & $\mathrm{C} 1$ & & & $6(2.3)$ & $4(1.9)$ \\
\hline
\end{tabular}

Note: $\mathrm{F}=$ soil surface crusting, $\mathrm{C}=$ cover percentage, $\mathrm{R}=$ roughness. Values in brackets relate to standard deviation of measurements). Bold typeface values are measurements with the Mini-Disk; italic typeface estimated values.

unsaturated hydraulic conductivities for higher soil suctions. It may thus underestimate infiltration capacity because macropores are already desaturated at the first suction head (Bhave and Sreeja, 2013). However, Bhave and Sreeja (2013) reported marginal differences in infiltration rates if measurements are taken when the soil water content is high and if a low suction head (close to the saturation) is used. For that reason, measurements were performed on relatively wet soil two days after several rainfall events and the suction head of the tension infiltrometer was $2 \mathrm{~cm}$. In addition, De Pue et al. (2019) reported that the determination of the hydraulic conductivity between 0 and $-100 \mathrm{~cm}$ of matric head is overestimated using $\mathrm{Ks}$ and $\mathrm{K}(\mathrm{h})$ measurements. The best precision is achieved with only $K(h)$ measurements. For this reason, the authors recommended to add Mini Disk measurements in order to better approach $\mathrm{K}(\mathrm{h})$ between 0 and $-100 \mathrm{~cm}$. The use of a constant head infiltrometer was not possible because it is a destructive method for fields (farmers denied permission).

Table $\mathrm{V}$ presents potential sediment concentration in the water flow for all combinations of soil surface properties and 
Table V. Potential sediment concentration $\left(\mathrm{g} \mathrm{l}^{-1}\right)$ for each combination of soil surface properties and rainfall intensity at six minutes time step for the Belgian loess belt (Evrard et al., 2009)

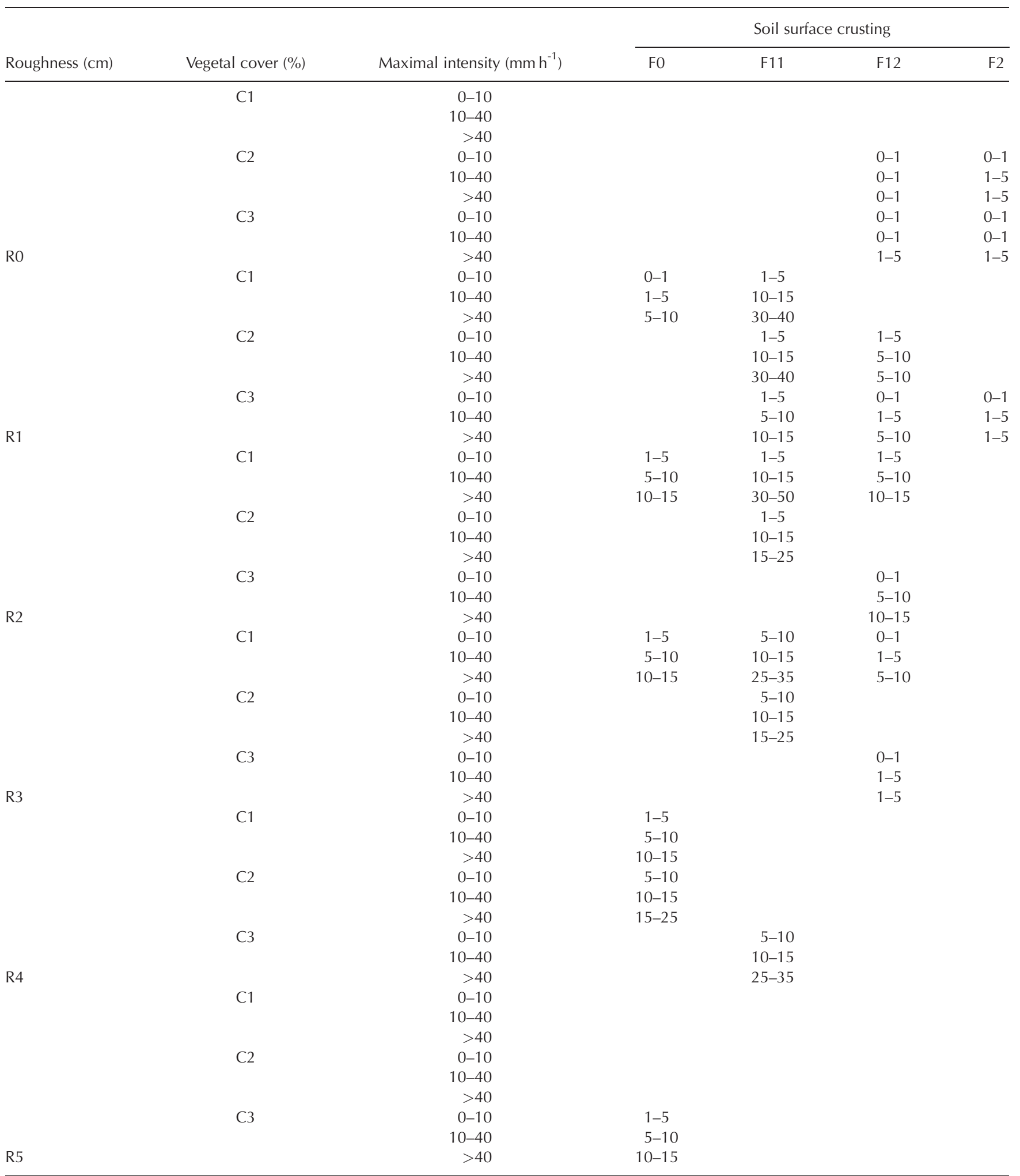

Note: $\mathrm{F}=$ soil surface crusting, $\mathrm{C}=$ cover percentage, $\mathrm{R}=$ roughness.

rainfall intensities. These values were adapted for the Belgian loess belt by Evrard et al. (2009). Values come from measurements on two catchments in central Belgium (4 and 5 ha) with samplings of storm runoff and seasonal correction. The quality of the adaptation was considered to be good with a root mean square error $(\mathrm{RMSE})=0.05 \mathrm{~T} \mathrm{ha}^{-1} \mathrm{yr}^{-1}$ (Evrard et al., 2009). The central value of the classes was used in the model.

Rules for rill erosion and prediction of ephemeral gullies from Souchère et al. (2003) were applied without any changes.
Rainfall events selection

To select rainfall events, a list of all rainfall events during the monitoring period was made. Each rainfall event was separated by three hours without rain. Water amount, duration, effective duration (intensity $>2 \mathrm{~mm} \mathrm{~h}^{-1}$ ), maximal intensity at one minute time step (in $\mathrm{mm} \mathrm{h}^{-1}$ ), time of beginning and 48 hourantecedent rainfall were calculated for each event. All the data were derived from the rainfall gauge except the maximal intensity which was calculated using the disdrometer. The second 
step was to select effective rainfalls, i.e. rainfall events producing significant runoff. For that purpose, a peak height of $20 \mathrm{~cm}$ at the outlet flume was arbitrarily defined as the threshold value, corresponding to a discharge of $22 \mathrm{Is}^{-1}$ (Data S1).

The time step used for rainfall was one minute because this is the most accurate step to calculate the effective duration of rainfall (measurement time of the pluviometer and the disdrometer). The rainfall selection procedure selected $83 \%$ of the total rainfall amount and $92 \%$ of the rainfall erosivity for the period using Wischmeier and Smith's (1978) method.

\section{Imbibition rainfall}

The imbibition rainfall table was adapted to the catchment, using the rainfall gauge and the flowmeter at point 1 . For all rainfall events during the winter period (saturation overland flow), the time of the last rainfall and the amount of rainfall between the beginning of the rainfall event and the beginning of the runoff was calculated. Using a percentage of area of each land use uphill of the measurement, a mean and standard deviation for each level of 48 hour-antecedent rainfall and for each class of sensitivity to runoff (equal to the different infiltration capacities) could be calculated. Table VI presents

Table VI. Imbibition rainfall for each class of 48 hour-antecedent rainfall and each soil sensitivity to runoff class

\begin{tabular}{lllll}
\hline P48 & \multicolumn{1}{c}{0} & $0-15$ & $15-40$ & $>40 \mathrm{~mm}$ \\
\hline CS & $9(6.7)$ & $6(3.5)$ & $4(3.1)$ & - \\
0 & $9(6.7)$ & $6(3.5)$ & $4(3.1)$ & - \\
1 & $7.3(5.2)$ & $4.7(2.9)$ & $2.6(2.3)$ & - \\
2 & $3.7(2.6)$ & $2.3(1.4)$ & $1.3(1.1)$ & - \\
3 & $2.4(1.7)$ & $1.6(1)$ & $0.9(0.8)$ & - \\
4 & $1.8(1.3)$ & $1.2(0.7)$ & $0.6(0.6)$ & - \\
5 & $1.8(1.3)$ & $1.2(0.7)$ & $0.6(0.6)$ & - \\
6 & $1.8(1.3)$ & $1.2(0.7)$ & $0.6(0.6)$ & - \\
7 & $1.8(1.3)$ & $1.2(0.7)$ & $0.6(0.6)$ & - \\
8 & $1.5(1)$ & $0.9(0.6)$ & $0.5(0.5)$ & - \\
9 & $1.5(1)$ & $0.9(0.6)$ & $0.5(0.5)$ & - \\
10 & 0 & 0 & 0 & - \\
11 & 0 & 0 & 0 & - \\
12 & 0 & 0 & 0 & - \\
13 & 0 & 0 & 0 & \\
14 & 0 & 0 & \\
\hline
\end{tabular}

Note: Values in italic typeface are calculated, standard deviation in brackets. imbibition rainfall for all classes of 48 hour-antecedent rainfall. Water quantities were much smaller than original values by Evrard et al. (2009), which is logical because infiltration capacity was also smaller.

\section{Field measurements}

For comparison purposes, graduated rulers were placed at various locations in the catchment to measure erosion and deposition. Within the catchment, 11, 6 and 10 zones with a total of 100, 51 and 65 rulers each were monitored for 2014, 2015 and 2016, respectively (Figure 3). Rulers were placed in the field not far from linear landscape elements (field boundaries, grass strips and woodland strip) in the flow paths of water and sediments between April and September for the three years. They could not be placed on hillslopes or throughout the year because of the technical operations of farmers. In 2014, zone 2014_8 was situated at a field boundary not far from the outlet, zones 2014_1,2014_2,2014_3 and 2014_5 were upstream of the woodland strip, zone 2014_7 before a grass strip, zones 2014_6 and 2014_9 in a field. In 2015, zone 2015_1 was situated at a field boundary, zones 2015_3, 2015_5 and 2015_6 in a field and zone 2015_4 before a grass strip. In 2016, zones 2016_2, 2016_3, 2016_6, 2016_8 and 2016_9 were situated at a field boundary, zone 2016_1 in a field and zones 2016_7 and 2016_10 before the woodland strip. Field observations including height of marker and deposit sampling (bulk density determination) were performed several times (1 April 2014, 3 June 2014, 17 July 2014, 14 August 2014, 25 April 2015, 9 June 2015, 9 July 2015, 29 June 2016, 11 July 2016 and 8 September 2016) in order to discriminate between successive large rainfall events.

Table VII. Rainfall and runoff amount for April-September 2014, 2015 and 2016

\begin{tabular}{ccccc}
\hline & $\begin{array}{c}\text { Rainfall } \\
\text { amount }(\mathrm{mm})\end{array}$ & $\begin{array}{c}\text { Selected } \\
\text { rainfall }(\mathrm{mm})\end{array}$ & $\begin{array}{c}\text { Runoff } \\
(\mathrm{mm})\end{array}$ & $\begin{array}{c}\text { Runoff } \\
\text { coefficient (\%) }\end{array}$ \\
\hline 2014 & 332.4 & 305.2 & 13.1 & 4.3 \\
2015 & 80.6 & 64.6 & 0.7 & 1.1 \\
2016 & 128.4 & 115.6 & 5.2 & 4.5 \\
\hline
\end{tabular}

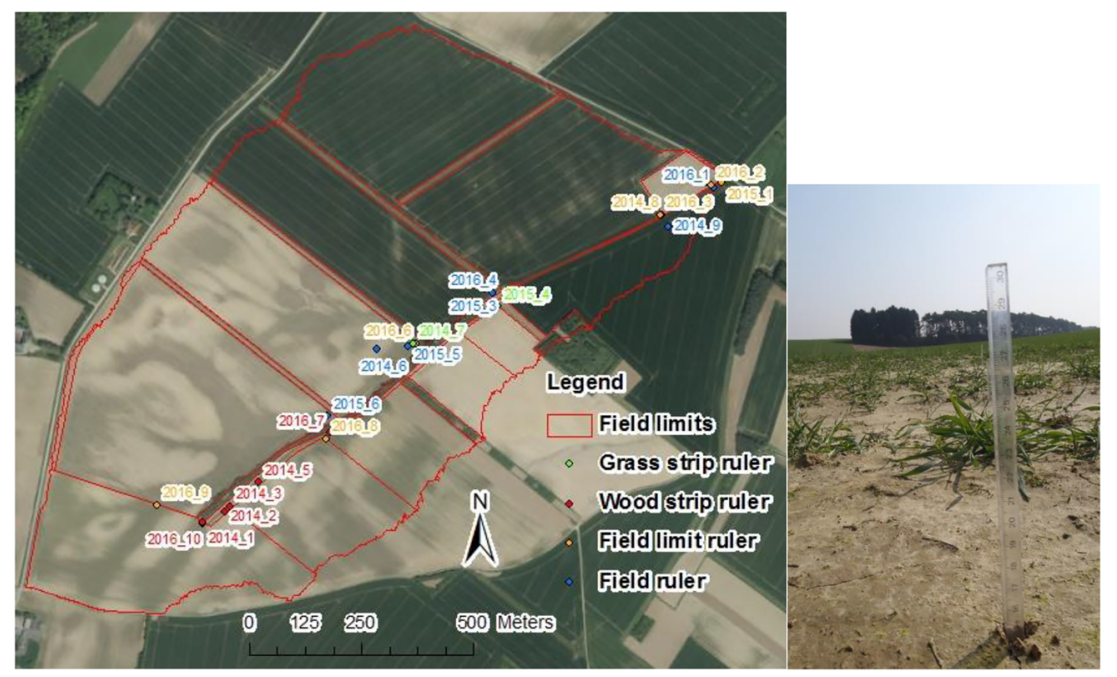

Figure 3. Position of rulers with graduated scale for model validation. [Colour figure can be viewed at wileyonlinelibrary.com] 


\section{Results and Discussion}

\section{Runoff}

Table VII presents rainfall and runoff amounts for events when field measurements were recorded in 2014, 2015 and 2016. The global runoff coefficient was quite small for the three years, indicating that small amounts of water and sediments reached the outlet even though some are mobilized in the catchment. This underlines the importance of spatialized data and several monitoring points (Pineux et al., 2017a). In particular, for 2015 the value is very small compared to the literature (Cerdan et al., 2004; Evrard et al., 2008; Ryken et al., 2018) at about 1\%. In 2014 and 2016, the global runoff coefficients were respectively equal to 4.3 and $4.5 \%$. The largest value for 2016 was linked to a high proportion of row crops: 90\% (45 and 39\% for 2014 and 2015). In addition, the disappearance of grass strips and some field boundaries might have resulted in higher hydrological connectivity for 2016. For 2014, the value of the runoff coefficient was mainly due to rainfalls in June. This represented the most erosive month. The percentage soil cover in row crops was limited (Table II), leading to the highest value of Wischmeier C-factor (Maugnard et al., 2013).

Figure 4 presents results for point 1 . There is a good agreement between measured and modelled runoff volumes with a linear adjustment of $0.88^{*} x$, an $r^{2}$ of 0.96 and a NashSutcliffe criterion of 0.95 . Results are comparable to those of Cerdan et al. (2002b) and Evrard et al. (2009). Based on the
Nash-Sutcliffe criterion, the model performance is very good (Moriasi et al., 2007).

Figure 5 presents runoff results for point 2 . This point is situated uphill in the catchment ( $3.9 \mathrm{ha})$, thus most events generated no (measured and modelled) or very little runoff. The adjustment $\left(1.00 * x\right.$ with an $r^{2}$ of 0.28 and a Nash-Sutcliffe criterion of -0.47 ) shows a poor adjustment. Most events indicate no measured but little modelled runoff (between 0 and $30 \mathrm{~m}^{3}$ ). Most of these events correspond to long-lasting or low-intensity events. According to Evrard et al. (2009), LandSoil (STREAM) was not designed to simulate these types of events. The model is much more effective in predicting runoff generated by convective storms than during long-lasting and low-intensity events. The model does not take into account runoff caused by saturation. This is linked to the re-infiltration process. In long, low intensity rainfalls, runoff has more time for re-infiltration. Time taken for runoff to go to the outlet is not calculated in the model. This is one hypothesis to explain the relation between modelled and observed runoff volume for point 2. An important point shown here is the scaling effect of the runoff modelling. Cerdan et al. (2004) demonstrated a big difference in runoff response in relation to the contributing area (or size of the catchment). This is linked to different connectivity processes occurring, implying a different behaviour of the system. Modelled runoff coefficients and volumes are bigger when the size of the contributing area decreases. The LandSoil (STREAM) model aggregates processes at the event timescale and at field spatial scale which leads to difficulties in modelling small areas with a single land use.

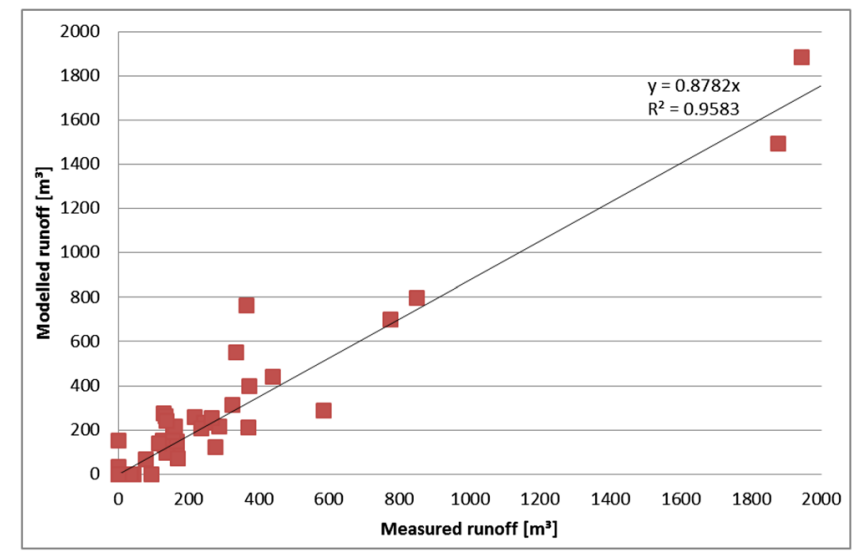

Figure 4. Comparison between measured and modelled runoff for point 1 (2014, 2015 and 2016). [Colour figure can be viewed at wileyonlinelibrary.com]

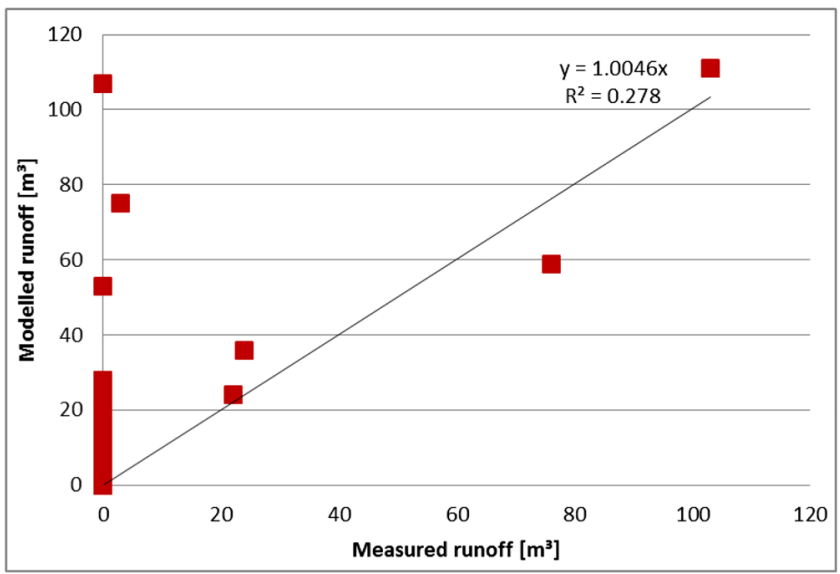

Figure 5. Comparison between measured and modelled runoff for point 2 (2014, 2015 and 2016). [Colour figure can be viewed at wileyonlinelibrary.com] 


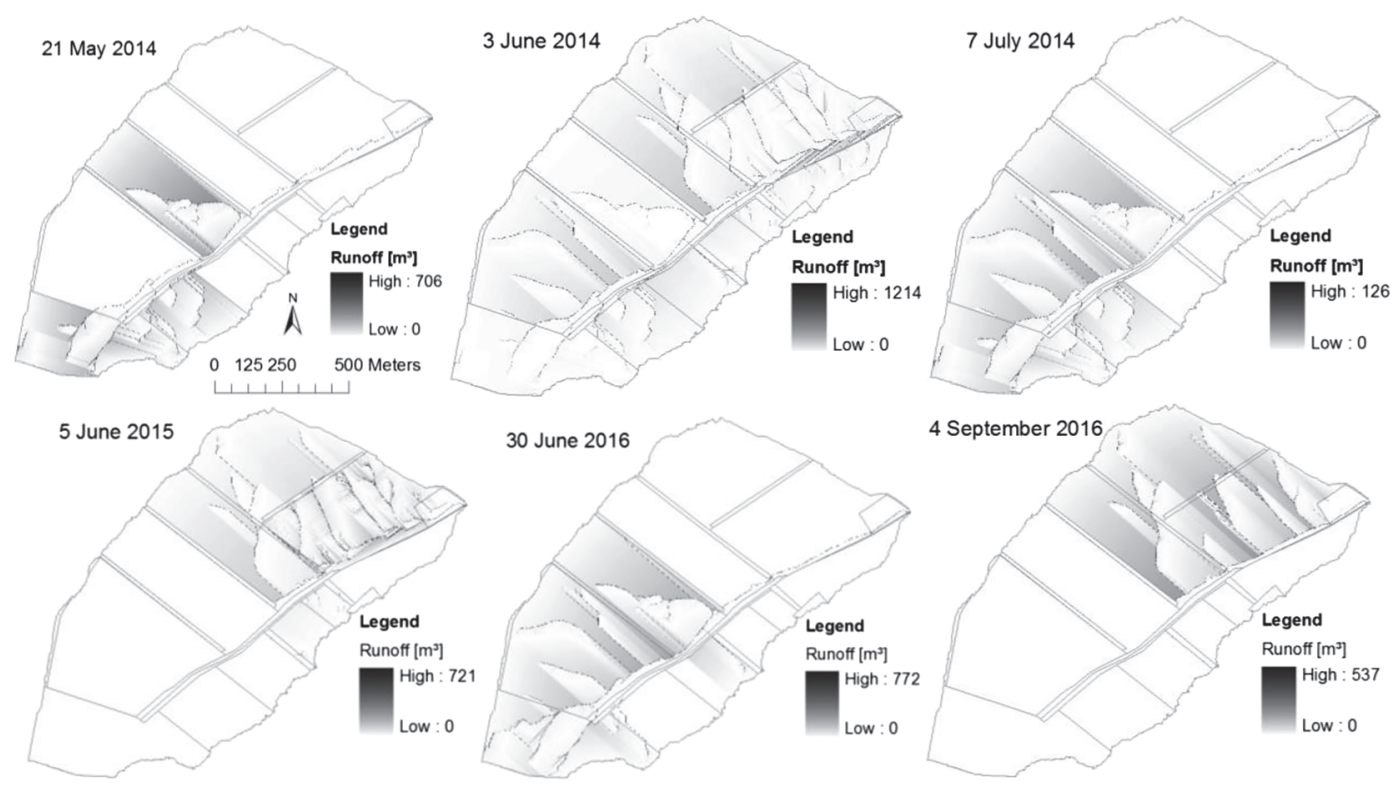

Figure 6. Predicted runoff volume accumulation for six rainfall events (21 May 2014, 3 June 2014, 7 July 2014, 5 June 2015,30 June 2016 and 4 September 2016).

Figure 6 presents the predicted spatial pattern of runoff for six different rainfall events chosen among all simulations to represent contrasted situations (21 May 2014, 3 June 2014, 7 July 2014, 5 June 2015, 30 June 2016 and 4 September 2016). Depending on the year and the time of the year (Figure 2, Table II), runoff came from sugar beets, potatoes or cereals. Row crops produced runoff during spring and early summer when erosive rainfalls fall over partially covered soils. Cereals generated runoff for big events in spring and July and in September after harvest. This underlines the importance of land allocation regarding runoff throughout the year. In addition, landscape design (position of field boundaries, furrow and tillage directions) involves changes in runoff volume (3 June 2014), flow direction and consequent flow accumulation. This has a major influence on hydrological connectivity, modifying production and transfer of runoff through the catchment to the outlet.

\section{Erosion}

Figure 7 and Table VIII present the comparison between graduated ruler measurements and erosion modelling for the different linear landscape elements. The new DEM at the end of the period of interest is compared to the original DEM. This way,

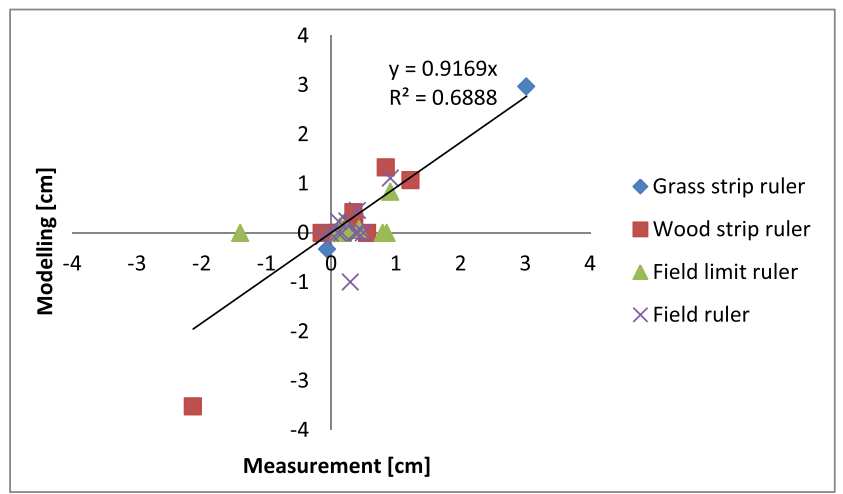

Figure 7. Comparison between graduated ruler measurements and erosion modelling for different types of features (positive values refer to deposition and negative values to erosion). [Colour figure can be viewed at wileyonlinelibrary.com] it is possible to compare observed and modelled erosion and deposition depths. For each zone, a mean and a standard deviation of the measured height variations are calculated. For the model, in order to take into account the uncertainty on the exact location, local pixel value and the two closest neighbours were considered.

There is a good agreement between measurement and modelling with a regression slope of 0.92 and an $r^{2}$ of 0.69 . The regression coefficients seem good but it is strongly influenced by the two extreme points. In addition, high standard deviations (Table VIII) do not allow conclusions to be drawn about the correct representation of erosion processes and their spatial pattern. There are many more results for deposition than for erosion (six erosion cases and 30 deposition cases). This is directly linked to the position of the rulers in fields. The location strategy aims to focus on deposition because LandSoil takes it into account. In addition, except for linear erosion in the stream, erosion places are characterized by little erosion on large areas (diffuse erosion) and are not measurable because of the rulers' precision.

Concerning the woodland strip, zone 2014_1 directly upstream of the woodland strip presents a high erosion rate between 1 April and 3 June 2014, $2.1 \mathrm{~cm}$ measured and $3.5 \mathrm{~cm}$ modelled. The sugar beet of the uphill field was characterized by low vegetation cover during the more erosive period in spring (188.8 $\mathrm{mm} \mathrm{h}^{-1}$ on 21 May 2014). This underlines that land use, and especially the use of row crops, has a strong impact on erosion rates (David et al., 2014). Figure 8 shows runoff (in $\mathrm{m}^{3} \mathrm{ha}^{-1}$ event ${ }^{-1}$ ) and erosion (in T ha ${ }^{-1} \mathrm{~m}^{-3}$ of runoff event ${ }^{-1}$ ) rates by land use for the three years studied. The runoff volume and sediment amounts were calculated for each land use by comparing input and output values for each field. Runoff is the highest for chicory $\left(2.4 \mathrm{~m}^{3}\right.$ ha $^{-1}$ event $\left.{ }^{-1}\right)$, potato $\left(1.9 \mathrm{~m}^{3} \mathrm{ha}^{-1}\right.$ event $\left.^{-1}\right)$, corn $\left(1.6 \mathrm{~m}^{3} \mathrm{ha}^{-1}\right.$ event $\left.{ }^{-1}\right)$ and sugar beet $\left(1.0 \mathrm{~m}^{3}\right.$ ha $^{-1}$ event $\left.^{-1}\right)$ confirming the impact of row crops. For erosion, results are more contrasted because linear erosion depends on the size of the accumulated channel and thus on the position in the catchment. For example, cereal has an erosion rate which is slightly higher than chicory. This is linked to the position of the cereal in 2014 and 2016 near the outlet. This involved high linear erosion rates because of water and sediment coming from upstream. Potato has the highest erosion rates, followed by corn and sugar beet. Corn fields in 2015 and 
Table VIII. Comparison between graduated ruler measurements and erosion modelling (positive values refer to deposition and negative values to erosion)

\begin{tabular}{|c|c|c|c|c|c|}
\hline & Date & $\begin{array}{c}\text { Measurement } \\
(\mathrm{cm})\end{array}$ & $\begin{array}{c}\text { Standard deviation } \\
\text { measurement } \\
(\mathrm{cm})\end{array}$ & $\begin{array}{c}\text { Mean model } \\
(\mathrm{cm})\end{array}$ & $\begin{array}{c}\text { Standard deviation } \\
\text { model }(\mathrm{cm})\end{array}$ \\
\hline \multicolumn{6}{|c|}{ Grass strip ruler } \\
\hline & 1 April => 3 June & 3.02 & 2.34 & 2.97 & 1.65 \\
\hline & 3 June $=>17$ July & 0.14 & 0.55 & 0 & 0 \\
\hline 2014_7 & 17 July $=>14$ August & -0.06 & 0.17 & -0.33 & 0.56 \\
\hline \multicolumn{6}{|c|}{ Wood strip ruler } \\
\hline & 1 April => 3 June & -2.13 & 1.15 & -3.52 & 6.06 \\
\hline 2014_1 & 3 June $=>17$ July & 0.85 & 0.58 & 1.33 & 2.02 \\
\hline 2014_2 & 3 June $=>17$ July & 0.14 & 0.75 & 0 & 0 \\
\hline \multirow[t]{3}{*}{$2014 \_3$} & 3 June $=>17$ July & 0.56 & 1.16 & 0 & 0 \\
\hline & 1 April => 3 June & 0.36 & 0.48 & 0.23 & 0.3 \\
\hline & 3 June $=>17$ July & 0.29 & 0.49 & 0.06 & 0.03 \\
\hline 2016_7 & 29 June $=>11$ July & 0.11 & 0.33 & 0 & 0 \\
\hline 2016_10 & 29 June $=>8$ September & 1.23 & 0.71 & 1.07 & 1.33 \\
\hline \multicolumn{6}{|c|}{ Field boundary ruler } \\
\hline & 1 April => 3 June & 0.43 & 0.62 & 0.08 & 0.02 \\
\hline 2014_8 & 3 June $=>14$ June & 0.14 & 0.27 & 0 & 0 \\
\hline \multirow[t]{2}{*}{ 2014_11 } & 3 June $=>14$ August & 0.14 & 0.38 & 0.13 & 0.09 \\
\hline & 25 April => 9 June & 0.92 & 0.66 & 0.83 & 1.44 \\
\hline 2015_1 & 9 June $=>9$ July & -1.40 & 2.07 & 0 & 0 \\
\hline 2016_2 & 29 June $=>8$ September & 0.23 & 0.54 & 0.07 & 0.01 \\
\hline 2016_3 & 29 June $=>11$ July & 0.11 & 0.29 & 0 & 0 \\
\hline 2016_6 & 29 June $=>8$ September & 0.19 & 0.47 & 0 & 0 \\
\hline 2016_8 & 29 June $=>8$ September & 0.86 & 1.30 & 0 & 0 \\
\hline 2016_9 & 29 June $=>8$ September & 0.80 & 1.18 & 0 & 0 \\
\hline \multicolumn{6}{|l|}{ Field ruler } \\
\hline 2014_4 & 3 June $=>17$ July & 0.50 & 0.29 & 0 & 0 \\
\hline \multirow[t]{2}{*}{$2014 \_6$} & 17 July $=>14$ August & 0.41 & 0.38 & 0.45 & 0.74 \\
\hline & 3 June $=>17$ July & 0.30 & 0.57 & -1.00 & 1.73 \\
\hline 2014_9 & 14 July $=>14$ August & 0.17 & 0.68 & 0 & 0 \\
\hline 2014_10 & 3 June $=>14$ August & 0.25 & 0.38 & 0.24 & 0.09 \\
\hline 2015_3 & 25 April => 9 June & -0.11 & 0.55 & -0.08 & 0.03 \\
\hline $2015 \_5$ & 9 June $=>9$ July & 0.38 & 0.55 & 0 & 0 \\
\hline 2015_6 & 9 June $=>9$ July & 0.42 & 0.42 & 0 & 0 \\
\hline 2016_1 & 29 June $=>11$ July & -0.01 & 0.25 & 0 & 0 \\
\hline 2016_4 & 29 June $=>11$ July & 0.11 & 0.35 & 0 & 0 \\
\hline
\end{tabular}

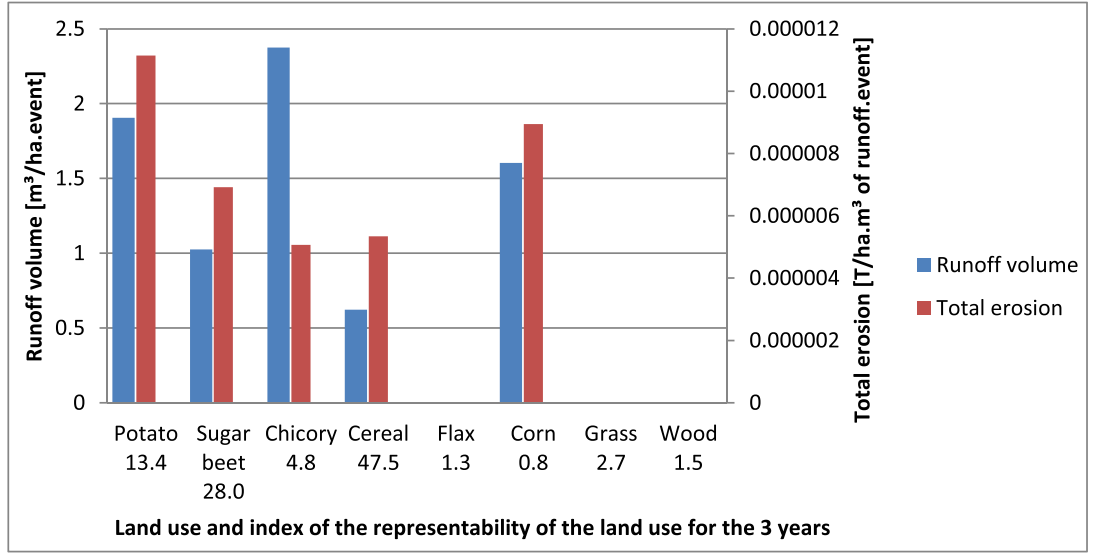

Figure 8. Bar chart of the modelled runoff volume $\left(\mathrm{m}^{3} \mathrm{ha}^{-1}\right.$ event $\left.{ }^{-1}\right)$ and modelled total erosion rate $\left(\mathrm{T} \mathrm{ha}^{-1} \mathrm{~m}^{-3}\right.$ of runoff event $\left.{ }^{-1}\right)$ by land use for 2014, 2015 and 2016. (Index between 0 and 100\% taking into account the area of land use and the number of events of the year: Index land use $=$ $\frac{\sum_{i=1}^{3} \text { area }_{i} * \text { number of event } \mathrm{s}_{\mathrm{i}}}{\sum_{i=1}^{3} \text { areatot } * \text { number of events } \mathrm{s}_{\mathrm{i}}}$ where $i=$ year.) [Colour figure can be viewed at wileyonlinelibrary.com] 
2016 were located uphill in the catchment, not in the concentrated flow paths. Sediments coming from these fields were only due to diffuse erosion and show strong erosion for corn.

The woodland strip induces less sediment deposition than grass strips mainly due to higher slope gradients upstream of the strip. Landscape design (position of strips, field boundaries and land-use allocation), associated with slope gradients, has a strong impact on runoff and erosion control, influencing connectivity on hillslopes (David et al., 2014).

Regarding the grass strips, zone 2014_7 directly upstream of a grass strip shows a deposition of more than $3 \mathrm{~cm}$ between 1 April and 3 June. This underlines the role of the grass strip in reducing runoff speed, to deposit eroded soil particles and thus to decrease connectivity (Ciampalini et al., 2012; Zhang et al., 2018). The very low slopes of this zone reinforce the deposition process. The upstream field was planted with sugar beet which induces high erosion rates during spring. Eroded sediments were deposited immediately before the grass strip. The other periods of the year and the other grass strips induced less sediment deposition because of respectively lower erosion rates and steeper slopes (Zhang et al., 2018).

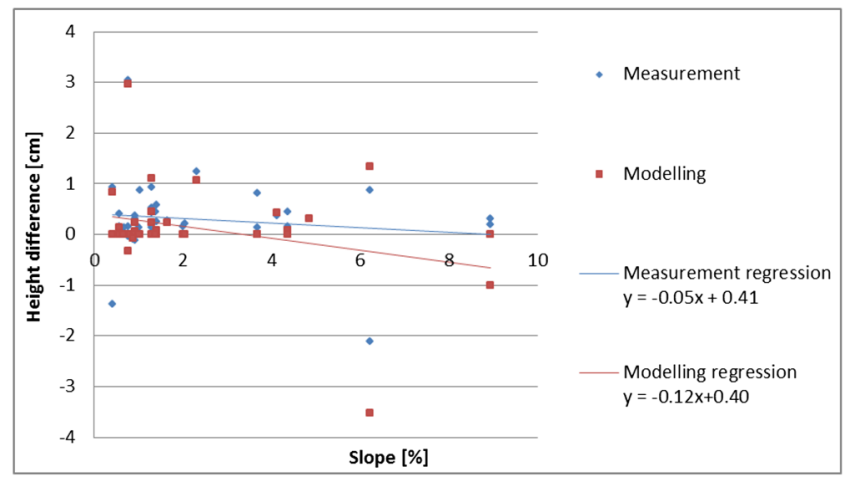

Figure 9. Graph of the height difference as a function of the slope for measurement and modelling (positive values refer to deposition and negative values to erosion). [Colour figure can be viewed at wileyonlinelibrary.com]
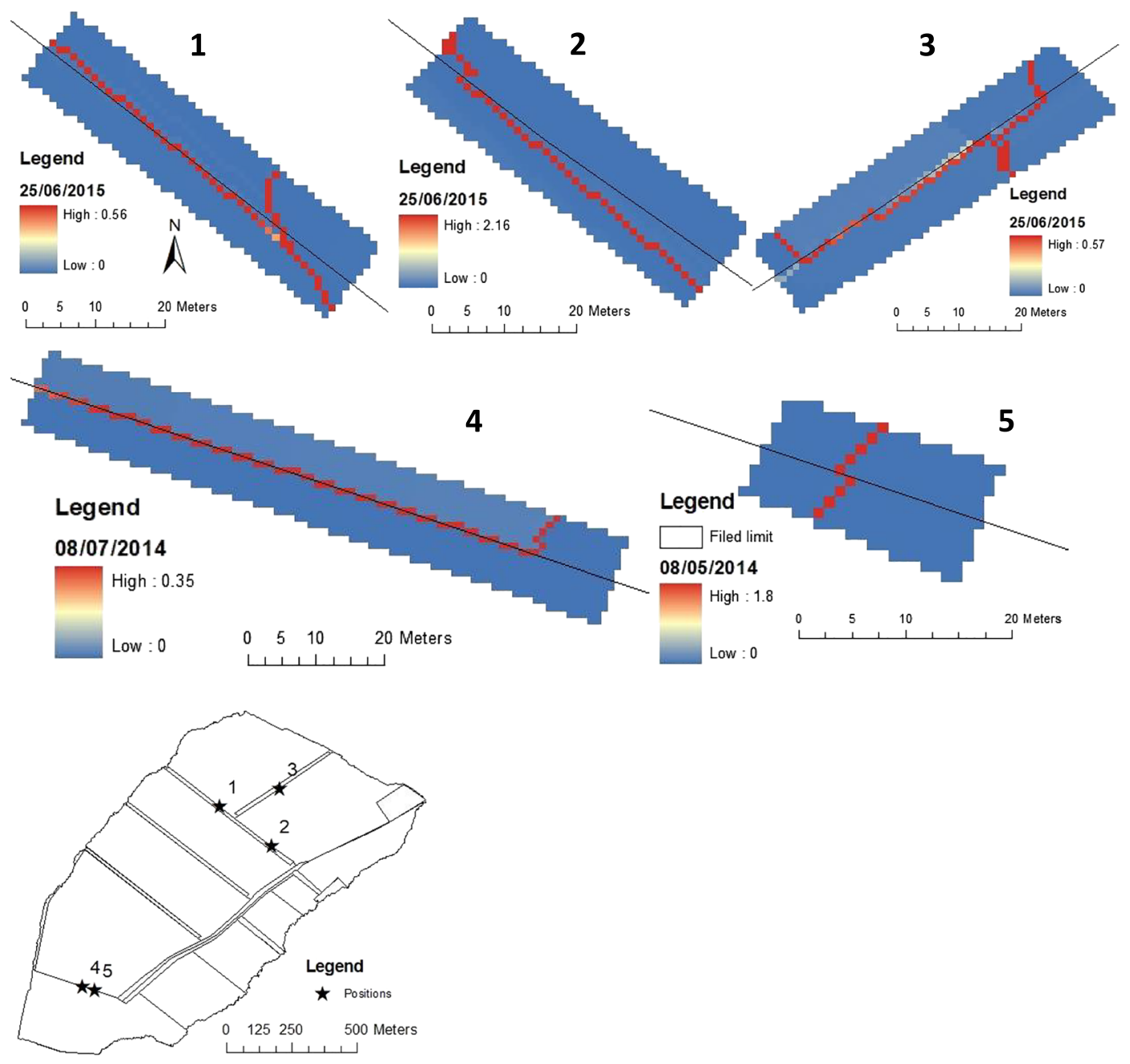

Figure 10. Total erosion $(\mathrm{T})$ at specified field boundaries. [Colour figure can be viewed at wileyonlinelibrary.com] 


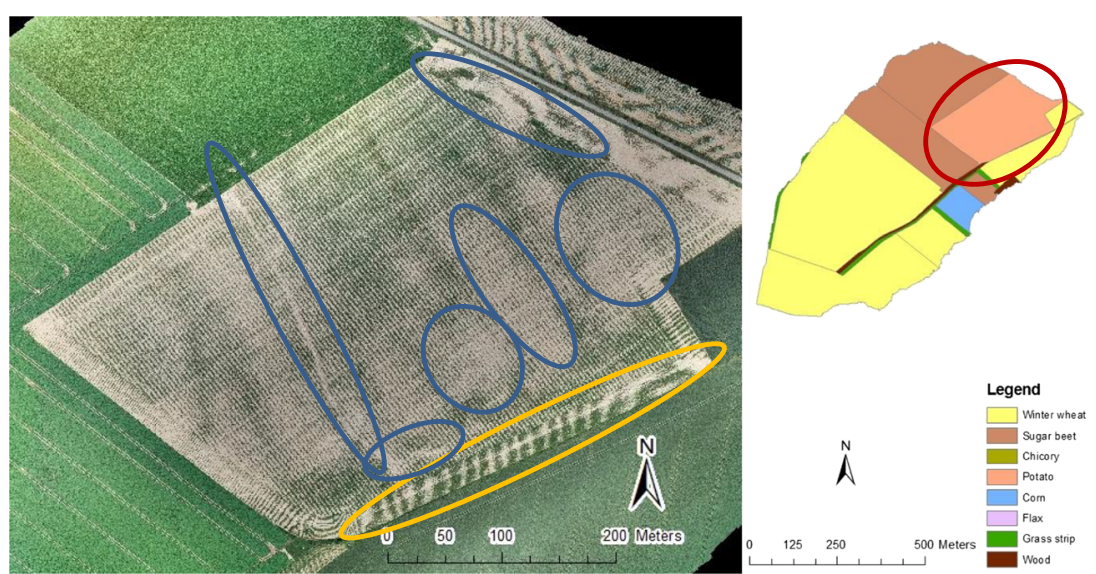

Figure 11. Orthophotoplan of 26 June 2019 after a large runoff event (10 June 2019) and the location of field, ephemeral gullies and deposition sites (blue: erosion sites, orange: deposition sites). [Colour figure can be viewed at wileyonlinelibrary.com]

Figure 9 describes the role of the slope in the erosion and deposition pattern. It shows a negative trend between height variations and slope. The trend is stronger for modelling than for measurement. The steeper the slope, the greater the erosion and the gentler the slope, the thicker the deposition. Of course, this trend must be nuanced by low slopes situated uphill in the catchment and associated with erosion, or by steeper slopes of field boundaries associated with deposition.

Field boundaries do not seem to play a great role in the amount of eroded and deposited particles but they influence the transport of particles by becoming a channel for small erosion rates. Figure 10 shows the total erosion rate at specified field boundaries. Field boundaries are a flow path for sediments (and runoff) when the erosion amount is low. At higher values, a flow path crosses the field boundary to go further in the catchment. As Figure 10 shows, the erosion amount is not deeply modified by passage along the field boundary.

As discussed, land-use allocation and landscape design have a great impact on erosion rate and connectivity. A high erosion rate involves considerable on-site damages with lots of sediment carried away. Connectivity is of even greater importance because it is responsible for off-site damages, the biggest economical and societal threat of erosion (Boardman et al., 2019). From 2014 to 2016, the disappearance of grass strips and some field boundaries increased the length of ephemeral gullies leading to higher connectivity and rising export of eroded sediments. Boardman and Vandaele (2016) showed that large areas of single crops lead to longer ephemeral gullies and a reduction of potential deposition sites. In 2019, management practices returned to older field boundaries, thereby limiting the length of flow paths and maintaining more deposition sites (Figure 11). It limits export of sediments by decreasing sediment connectivity.

\section{Conclusions}

The objective of this study was to test the capacity of an expert-based model (LandSoil) to represent erosion and deposition in a cultivated catchment in Belgium. Specific attention was given to the behaviour of some connectivity features, especially linear landscape elements. The catchment scale was used in this study since it is the most appropriate scale to investigate hydrological or sediment connectivity and to design integrated mitigation measures (Brocca et al., 2012; Rogger et al., 2017).

The rainfall selection permitted the inclusion of $92 \%$ of the erosivity in the model using three different criteria. A measurement campaign using a Mini Disk tension infiltrometer in June 2018 and 2019 highlighted much smaller infiltration capacities than those reported by Evrard et al. (2009) who first adapted the model parameters for central Belgium. This is mainly due to differences in texture, especially sand percentage. The infiltration capacity, related to soil surface crusting, soil roughness and vegetation cover, was identified as the second most sensitive input in the model after the rainfall amount (Ciampalini et al., 2017). The imbibition rainfall table was adapted to the catchment and also shows lower values than previous ones, suggesting that even in homogeneous regions like the loess belt, infiltration and imbibition rules must be updated.

Comparison between measured and modelled runoff volumes showed very close correspondence for the 84 ha subcatchment. For point 2, there were too few runoff events to conclude the quality of the modelling. The small contributing area (3.9 ha) shows too high a modelled runoff because of a scaling effect, confirming that LandSoil is not able to correctly model a small area with homogeneous land use. The good agreement between measurements and model for the largest subcatchment allowed the erosion pattern to be compared, which was calculated on the basis of the runoff volume.

Graduated rulers permitted the evaluation of modelling outputs at some locations in the catchment. The comparison for the 27 measurement zones was satisfactory, although standard deviations of measurements and modelling remained high. Land-use and field allocation have a very strong influence on erosion generation and sediment movement in the catchment. David et al. (2014) found similar results. Landscape design associated with slope gradients represents other characteristics that have great influence on erosion and deposition processes. Field boundaries do not seem to have a big impact on amounts of eroded and deposited particles, but played a role in transport acting as a channel for small erosion rates. Grass strips deposited sediment because of runoff speed reduction and infiltration in the strip, although other processes could interact. The process is amplified by low slopes in addition to the grass strip and confirmed the considerable interaction between grass strips and topography for erosion management (Boubakari and Morgan, 2006; Zhang et al., 2018). The woodland strip deposited less soil than grass strips because of steeper slopes upstream.

All these measurements tested the modelling of erosion processes for the studied catchment. The role of linear landscape elements could be highlighted. A study with more rulers 
could improve results. Rulers were placed in the thalweg between April and September; it would be interesting to also have results for hillslopes and in the winter period. Other methods could also help to reach objectives, like drones (Pineux et al., 2017a) with subtraction of successive flights, radionuclides (Le Gall et al., 2016; Meusburger et al., 2016) or other tracers (Ryken et al., 2018; Steegen et al., 2000).

The quite good behaviour of the model allows us to use LandSoil modelling in other environments, with other land use and different slopes to those of the study zone, and to quantify the impact of management scenarios.

Acknowledgements—Many thanks to Olivier Cerdan for his support in modelling aspects and reviewing this research. Thanks to Cate Chapman for the English review.

\section{Conflict of Interest Statement}

No conflict of interest.

\section{Data Availability Statement}

Research data are not shared.

\section{References}

Akram S, Yu B, Ghadiri H, Rose C, Hussein J. 2014. The links between water profile, net deposition and erosion in the design and performance of stiff grass hedges. Journal of Hydrology 510: 472-479. https://doi.org/10.1016/j.jhydrol.2014.01.001.

Baartman JEM, Masselink R, Keesstra SD, Temme AJAM. 2013. Linking landscape morphological complexity and sediment connectivity. Earth Surface Processes and Landforms 38: 1457-1471. https://doi. org/10.1002/esp.3434.

Bhave S, Sreeja P. 2013. Influence of initial soil condition on infiltration characteristics determined using a disk infiltrometer. ISH Journal of Hydraulic Engineering 19: 291-296. https://doi.org/10.1080/ 09715010.2013 .808445$.

Biddoccu M, Ferraris S, Pitacco A, Cavallo E. 2017. Temporal variability of soil management effects on soil hydrological properties, runoff and erosion at the field scale in a hillslope vineyard, north-west Italy. Soil and Tillage Research 165: 46-58. https://doi.org/10.1016/j. still.2016.07.017.

Bielders CL, Ramelot C, Persoons E. 2003. Farmer perception of runoff and erosion and extent of flooding in the silt-loam belt of the Belgian Walloon Region. Environmental Science \& Policy 6: 85-93. https:// doi.org/10.1016/S1462-9011(02)00117-X.

Blöschl G, Sivapalan M. 1995. Scale issues in hydrological modelling: a review. Hydrological Processes 9(3-4): 251-290.

Boardman J. 2010. A short history of muddy floods. Land Degradation \& Development 21: 303-309. https://doi.org/10.1002/ldr.1007.

Boardman J. 1988. Severe erosion on agricultural land in east Sussex, UK October 1987. Soil Technology 1: 333-348. https://doi.org/ 10.1016/0933-3630(88)90013-X.

Boardman J, Vandaele K. 2016. Effect of the spatial organization of land use on muddy flooding from cultivated catchments and recommendations for the adoption of control measures. Earth Surface Processes and Landforms 41: 336-343. https://doi.org/10.1002/esp.3793.

Boardman J, Vandaele K. 2010. Soil erosion, muddy floods and the need for institutional memory. Area 42: 502-513. https://doi.org/ 10.1111/j.1475-4762.2010.00948.x.

Boardman J, Vandaele K, Evans R, Foster IDL. 2019. Off-site impacts of soil erosion and runoff: why connectivity is more important than erosion rates. Soil Use and Management 35: 245-256. https://doi.org/ 10.1111/sum.12496.

Boiffin J. 1986. Stages and time dependency of soil crusting in situ. In Assessment of Soil Surface Sealing and Crusting, Caillebaud F,
Gabriels D, De Boodt M (eds). Flanders Research Center for Soil Erosion and Soil Conservation: Ghent.

Boll J, Brooks ES, Crabtree B, Dun S, Steenhuis TS. 2015. Variable source area hydrology modeling with the water erosion prediction project model. JAWRA Journal of the American Water Resources Association 51: 330-342. https://doi.org/10.1111/1752-1688.12294. Boubakari M, Morgan RPC. 2006. Contour grass strips for soil erosion control on steep lands: a laboratory evaluation. Soil Use and Management 15: 21-26. https://doi.org/10.1111/j.1475-2743.1999. tb00057.x.

Bracken LJ, Croke J. 2007. The concept of hydrological connectivity and its contribution to understanding runoff-dominated geomorphic systems. Hydrological Processes 21: 1749-1763. https://doi.org/ 10.1002/hyp.6313.

Bracken LJ, Wainwright J, Ali GA, Tetzlaff D, Smith MW, Reaney SM, Roy AG. 2013. Concepts of hydrological connectivity: research approaches, pathways and future agendas. Earth-Science Reviews 119: 17-34. https://doi.org/10.1016/j.earscirev.2013.02.001.

Bresson L-M, Boiffin J. 1990. Morphological characterization of soil crust development stages on an experimental field. Geoderma 47: 301-325. https://doi.org/10.1016/0016-7061(90)90035-8.

Brocca L, Tullo T, Melone F, Moramarco T, Morbidelli R. 2012. Catchment scale soil moisture spatial-temporal variability. Journal of Hydrology 422-423: 63-75. https://doi.org/10.1016/j.jhydrol.2011. 12.039 .

Cantreul V, Bielders C, Calsamiglia A, Degré A. 2018. How pixel size affects a sediment connectivity index in central Belgium. Earth Surface Processes and Landforms 43(4): 884-893. https://doi.org/ 10.1002/esp.4295.

Cerdan O, Le Bissonnais Y, Couturier A, Saby N. 2002a. Modelling interrill erosion in small cultivated catchments. Hydrological Processes 16: 3215-3226. https://doi.org/10.1002/hyp.1098.

Cerdan O, Le Bissonnais Y, Govers G, Lecomte V, van Oost K, Couturier A et al. 2004. Scale effect on runoff from experimental plots to catchments in agricultural areas in Normandy. Journal of Hydrology 299: 4-14. https://doi.org/10.1016/j.jhydrol.2004.02.017.

Cerdan O, Souchère V, Lecomte V, Couturier A, Le Bissonnais Y. 2002b. Incorporating soil surface crusting processes in an expert-based runoff model: sealing and transfer by runoff and erosion related to agricultural management. CATENA 46: 189-205. https://doi.org/ 10.1016/S0341-8162(01)00166-7.

Ciampalini R, Follain S, Cheviron B, Le Bissonnais $Y$, Couturier A, Moussa R, Walter C. 2017. Local sensitivity analysis of the LandSoil erosion model applied to a virtual catchment. In Sensitivity Analysis in Earth Observation Modelling, Petropoulos GP, Srivastava PK (eds). Elsevier: Amsterdam; 55-73.

Ciampalini R, Follain S, Le Bissonnais Y. 2012. LandSoil: a model for analysing the impact of erosion on agricultural landscape evolution. Geomorphology 175-176: 25-37. https://doi.org/10.1016/j. geomorph.2012.06.014.

Couturier A, Daroussin J, Darboux F, Souchère V, Le Bissonnais $Y$, Cerdan O, King D. 2013. Improvement of surface flow network prediction for the modeling of erosion processes in agricultural landscapes. Geomorphology 183: 120-129. https://doi.org/10.1016/j. geomorph.2012.07.025.

Da Silva RM, Santos CAG, de Lima Silva VC, e Silva LP. 2013. Erosivity, surface runoff, and soil erosion estimation using GIS-coupled runofferosion model in the Mamuaba catchment, Brazil. Environmental Monitoring and Assessment 185: 8977-8990. https://doi.org/ 10.1007/s10661-013-3228-x.

David M, Follain S, Ciampalini R, Le Bissonnais Y, Couturier A, Walter C. 2014. Simulation of medium-term soil redistributions for different land use and landscape design scenarios within a vineyard landscape in Mediterranean France. Geomorphology 214: 10-21. https://doi.org/10.1016/j.geomorph.2014.03.016.

De Pue J, Rezaei M, Van Meirvenne M, Cornelis WM. 2019. The relevance of measuring saturated hydraulic conductivity: sensitivity analysis and functional evaluation. Journal of Hydrology 576: 628-638. https://doi.org/10.1016/j.jhydrol.2019.06.079.

Deletic A, Fletcher TD. 2006. Performance of grass filters used for stormwater treatment - a field and modelling study. Journal of Hydrology 317: 261-275. https://doi.org/10.1016/j.jhydrol.2005. 05.021 . 
Evrard O, Bielders CL, Vandaele K, van Wesemael B. 2007. Spatial and temporal variation of muddy floods in central Belgium, off-site impacts and potential control measures. CATENA 70: 443-454. https://doi.org/10.1016/j.catena.2006.11.011.

Evrard O, Cerdan O, van Wesemael B, Chauvet M, Le Bissonnais Y, Raclot D et al. 2009. Reliability of an expert-based runoff and erosion model: application of STREAM to different environments. CATENA 78: 129-141. https://doi.org/10.1016/j.catena.2009.03.009.

Evrard O, Nord G, Cerdan O, Souchère V, Le Bissonnais Y, Bonté P. 2010. Modelling the impact of land use change and rainfall seasonality on sediment export from an agricultural catchment of the northwestern European loess belt. Agriculture, Ecosystems \& Environment 138: 83-94. https://doi.org/10.1016/j.agee.2010.04.003.

Evrard O, Vandaele K, Bielders C, van Wesemael B. 2008. Seasonal evolution of runoff generation on agricultural land in the Belgian loess belt and implications for muddy flood triggering. Earth Surface Processes and Landforms 33: 1285-1301. https://doi.org/10.1002/ esp.1613.

Fiener P, Auerswald K, Van Oost K. 2011. Spatio-temporal patterns in land use and management affecting surface runoff response of agricultural catchments - a review. Earth-Science Reviews 106: 92-104. https://doi.org/10.1016/j.earscirev.2011.01.004.

Govers G, Everaert W, Poesen J, Rauws G, Ploey J, Lautridou J. 1990. A long flume study of the dynamic factors affecting the resistance of loamy soil to concentrated flow erosion. Earth Surface Processes and Landforms 15: 313-328. https://doi.org/10.1002/esp. 3290150403.

Govers G, Vandaele K, Desmet P, Poesen J, Bunte K. 1994. The role of tillage in soil redistribution on hillslopes. European Journal of Soil Science 45: 469-478. https://doi.org/10.1111/j.1365-2389.1994. tb00532.x.

Gumière SJ, Le Bissonnais Y, Raclot D, Cheviron B. 2011. Vegetated filter effects on sedimentological connectivity of agricultural catchments in erosion modelling: a review. Earth Surface Processes and Landforms 36: 3-19. https://doi.org/10.1002/esp.2042.

Heckmann T, Gegg K, Gegg A, Becht M. 2014. Sample size matters: investigating the effect of sample size on a logistic regression susceptibility model for debris flows. Natural Hazards and Earth System Sciences 14: 259-278. https://doi.org/10.5194/nhess-14-259-2014.

Hurst MD, Mudd SM, Walcott R, Attal M, Yoo K. 2012. Using hilltop curvature to derive the spatial distribution of erosion rates. Journal of Geophysical Research: Earth Surface 117, F02017. https://doi.org/ 10.1029/2011JF002057.

Hutton C, Nicholas A, Brazier R. 2014. Sub-grid scale parameterization of hillslope runoff and erosion processes for catchment-scale models of semi-arid landscapes: sub-grid scale runoff and erosion modelling. Hydrological Processes 28: 1713-1721. https://doi.org/10.1002/ hyp. 9712 .

Jetten V, Govers G, Hessel R. 2003. Erosion models: quality of spatial predictions. Hydrological Processes 17: 887-900. https://doi.org/ 10.1002/hyp.1168.

Kader MA, Sleutel S, Begum SA, D'Haene K, Jegajeevagan K, De Neve S. 2010. Soil organic matter fractionation as a tool for predicting nitrogen mineralization in silty arable soils. Soil Use and Management 26: 494-507. https://doi.org/10.1111/j.1475-2743.2010.00303.x.

Lacoste M, Michot D, Viaud V, Evrard O, Walter C. 2014. Combining 137Cs measurements and a spatially distributed erosion model to assess soil redistribution in a hedgerow landscape in northwestern France (1960-2010). CATENA 119: 78-89. https://doi.org/10.1016/ j.catena.2014.03.004.

Lane L, Nichols M, Paige G. 1995. Modelling erosion on hillslopes: Concepts, theory and data. Catena 1: 1-7.

Le Bissonnais Y, Benkhadra H, Chaplot V, Fox D, King D, Daroussin J. 1998. Crusting, runoff and sheet erosion on silty loamy soils at various scales and upscaling from $\mathrm{m} 2$ to small catchments. Soil and Tillage Research 46: 69-80. https://doi.org/10.1016/S0167-1987(98) 80109-8.

Le Bissonnais $\mathrm{Y}$, Cerdan $\mathrm{O}$, Lecomte $\mathrm{V}$, Benkhadra $\mathrm{H}$, Souchère $\mathrm{V}$, Martin P. 2005. Variability of soil surface characteristics influencing runoff and interrill erosion. CATENA 62: 111-124. https://doi.org/ 10.1016/j.catena.2005.05.001.

Le Gall M, Evrard O, Foucher A, Laceby JP, Salvador-Blanes S, Thil F et al. 2016. Quantifying sediment sources in a lowland agricultural catchment pond using $137 \mathrm{Cs}$ activities and radiogenic $87 \mathrm{Sr} / 86 \mathrm{Sr}$ ratios. Science of the Total Environment 566-567: 968-980. https://doi. org/10.1016/j.scitotenv.2016.05.093.

Lecomte V. 1999. Transfert de produits phytosanitaires par le ruissellement et l'érosion de la parcelle au bassin versant: processus, déterminisme et modélisation spatiale, Thesis. French National School of Forestry: Paris.

Lesschen JP, Schoorl JM, Cammeraat LH. 2009. Modelling runoff and erosion for a semi-arid catchment using a multi-scale approach based on hydrological connectivity. Geomorphology 109: 174-183. https://doi.org/10.1016/j.geomorph.2009.02.030.

Liu XC, Gao T, Liu L. 2013. A comparison of rainfall measurements from multiple instruments. Atmospheric Measurement Techniques 6: 1585-1595. https://doi.org/10.5194/amt-6-1585-2013.

Liu Y, Fu B. 2016. Assessing sedimentological connectivity using WATEM/SEDEM model in a hilly and gully watershed of the Loess Plateau, China. Ecological Indicators 66: 259-268. https://doi.org/ 10.1016/j.ecolind.2016.01.055.

López-Vicente M, Poesen J, Navas A, Gaspar L. 2013. Predicting runoff and sediment connectivity and soil erosion by water for different land use scenarios in the Spanish Pre-Pyrenees. CATENA 102: 62-73. https://doi.org/10.1016/j.catena.2011.01.001.

Maugnard A, Bielders C, Bock L, Colinet G, Cordonnier H, Degré A et al. 2013. Cartographie du risque d'érosion hydrique à l'échelle parcellaire en soutien à la politique agricole wallonne (Belgique). Etudes et Gestion des Sols 20: 127-141.

Maugnard A, Cordonnier H, Degré A, Demarcin P, Pineux N, Bielders CL. 2014. Uncertainty assessment of ephemeral gully identification, characteristics and topographic threshold when using aerial photographs in agricultural settings. Earth Surface Processes and Landforms 39: 1319-1330. https://doi.org/10.1002/esp.3526.

Medeiros PHA, Güntner A, Francke T, Mamede GL, Carlos de Araújo J. 2010. Modelling spatio-temporal patterns of sediment yield and connectivity in a semi-arid catchment with the WASA-SED model. Hydrological Sciences Journal 55: 636-648. https://doi.org/ 10.1080/02626661003780409.

Meusburger K, Mabit L, Ketterer M, Park J-H, Sandor T, Porto P, Alewell C. 2016. A multi-radionuclide approach to evaluate the suitability of $239+240 \mathrm{Pu}$ as soil erosion tracer. Science of the Total Environment 566-567: 1489-1499. https://doi.org/10.1016/j.scitotenv.2016. 06.035 .

Moriasi DN, Arnold JG, Van Liew MW, Bingner RL, Harmel RD, Veith TL. 2007. Model evaluation guidelines for systematic quantification of accuracy in watershed simulations. Transactions of the ASABE 50: 885-900.

Navarro-Hevia J, Lima-Farias TR, de Araújo JC, Osorio-Peláez C, Pando V. 2015. Soil erosion in steep road cut slopes in Palencia (Spain). Land Degradation \& Development 27: 190-199. https://doi.org/ 10.1002/ldr.2459.

Nearing M, Pruski F, O'Neal MR. 2004. Expected climate change impacts on soil erosion rates: a review. Journal of Soil and Water Conservation 59(1): 43-50.

Nunes JP, Wainwright J, Bielders C, Darboux F, Fiener P, Finger D, Turnbull L. 2018. Better models are more effectively connected models. Earth Surface Processes and Landforms 43(6): 1355-1360.

Paroissien J-B, Darboux F, Couturier A, Devillers B, Mouillot F, Raclot D, Le Bissonnais Y. 2015. A method for modeling the effects of climate and land use changes on erosion and sustainability of soil in a Mediterranean watershed (Languedoc, France). Journal of Environmental Management 150: 57-68. https://doi.org/10.1016/j. jenvman.2014.10.034.

Pineux N, Lisein J, Swerts G, Bielders CL, Lejeune P, Colinet G, Degré A. 2017a. Can DEM time series produced by UAV be used to quantify diffuse erosion in an agricultural watershed? Geomorphology 280: 122-136. https://doi.org/10.1016/j.geomorph.2016.12.003.

Pineux N, Michel B, Legrain X, Bielders CL, Degré A, Colinet G. 2017b. Diachronic soil surveys: a method for quantifying long-term diffuse erosion? Geoderma Regional 10: 102-114. https://doi.org/10.1016/ j.geodrs.2017.06.001.

Région Wallonne. 2015. Rapport de production du Relief de la Wallonie 2013-2014. Belgium.

Rodríguez-Blanco ML, Taboada-Castro MM, Taboada-Castro MT. 2013. Linking the field to the stream: soil erosion and sediment yield 
in a rural catchment, NW Spain. CATENA 102: 74-81. https://doi. org/10.1016/j.catena.2010.09.003.

Rogger M, Agnoletti M, Alaoui A, Bathurst JC, Bodner G, Borga M et al. 2017. Land use change impacts on floods at the catchment scale: challenges and opportunities for future research: land use change impacts on floods. Water Resources Research 53: 5209-5219. https:// doi.org/10.1002/2017WR020723.

Rose CW, Yu B, Hogarth WL, Okom AEA, Ghadiri H. 2003. Sediment deposition from flow at low gradients into a buffer strip-a critical test of re-entrainment theory. Journal of Hydrology 280: 33-51. https://doi.org/10.1016/S0022-1694(03)00184-7.

Ryken N, Vanden Nest T, Al-Barri B, Blake W, Taylor A, Bodé S et al. 2018. Soil erosion rates under different tillage practices in central Belgium: new perspectives from a combined approach of rainfall simulations and 7Be measurements. Soil and Tillage Research 179: 29-37. https://doi.org/10.1016/j.still.2018.01.010.

Seyfried MS, Wilcox BP. 1995. Scale and the nature of spatial variability: field examples having implications for hydrologic modeling. Water Resources Research 31: 173-184. https://doi.org/10.1029/ 94WR02025.

Singh R, Wagener T, van Werkhoven K, Mann ME, Crane R. 2011. A trading-space-for-time approach to probabilistic continuous streamflow predictions in a changing climate - accounting for changing watershed behavior. Hydrology and Earth System Sciences 15: 3591-3603.

Smith HG, Peñuela A, Sangster H, Sellami H, Boyle J, Chiverrell R et al. 2018. Simulating a century of soil erosion for agricultural catchment management. Earth Surface Processes and Landforms 43: 2089-2105. https://doi.org/10.1002/esp.4375.

Souchère $\mathrm{V}$, Cerdan $\mathrm{O}$, Ludwig $\mathrm{B}$, Le Bissonnais $\mathrm{Y}$, Couturier A, Papy F. 2003. Modelling ephemeral gully erosion in small cultivated catchments. CATENA 50: 489-505. https://doi.org/10.1016/S03418162(02)00124-8.

Souchère V, King D, Daroussin J, Papy F, Capillon A. 1998. Effects of tillage on runoff directions: consequences on runoff contributing area within agricultural catchments. Journal of Hydrology 206: 256-267. https://doi.org/10.1016/S0022-1694(98)00103-6.

Steegen A, Govers G, Beuselinck L, Van Oost K, Quine TA, Rombaut A. 2000. The Use of Phosphorus as a Tracer in Erosion/Sedimentation Studies. IAHS-AISH Publication: Wallingford; 59-66.

Takken I, Beuselinck L, Nachtergaele J, Govers G, Poesen J, Degraer G. 1999. Spatial evaluation of a physically-based distributed erosion model (LISEM). CATENA 37: 431-447. https://doi.org/10.1016/ S0341-8162(99)00031-4.

Takken I, Govers G, Jetten V, Nachtergaele J, Steegen A, Poesen J. 2005. The influence of both process descriptions and runoff patterns on predictions from a spatially distributed soil erosion model. Earth Surface Processes and Landforms 30: 213-229. https://doi.org/10.1002/ esp.1176.

Van Dijk PM, Kwaad FJPM, Klapwijk M. 1996. Retention of water and sediment by grass strips. Hydrological Processes 10: 1069-1080. https://doi.org/10.1002/(SICI)1099-1085(199608)10:8<1069::AIDHYP412>3.0.CO;2-4.

Van Muysen W, Govers G, Van Oost K, Van Rompaey A. 2000. The effect of tillage depth, tillage speed, and soil condition on chisel tillage erosivity. Journal of Soil and Water Conservation 55: 355-364.

Vandaele K, Poesen J. 1995. Spatial and temporal patterns of soil erosion rates in an agricultural catchment, central Belgium. CATENA 25: 213-226. https://doi.org/10.1016/0341-8162(95)00011-G.

Verstraeten G, Poesen J. 1999. The nature of small-scale flooding, muddy floods and retention pond sedimentation in central Belgium. Geomorphology 29: 275-292. https://doi.org/10.1016/ S0169-555X(99)00020-3.

Verstraeten G, Poesen J, Goossens D, Gillijns K, Bielders C, Gabriels D et al. 2006. Soil erosion in Belgium. In Soil Erosion in Europe, Boardman J, Poesen J (eds). John Wiley \& Sons: Chichester; 385-411.

Western AW, Blöschl G, Grayson RB. 2001. Toward capturing hydrologically significant connectivity in spatial patterns. Water Resources Research 37: 83-97. https://doi.org/10.1029/2000WR900241.

Wischmeier WH, Smith DD. 1978. Predicting Rainfall Erosion Losses: A Guide to Conservation Planning, Science and Education Administration. US Department of Agriculture: Washington, DC.

Zhang X, Li P, Li ZB, Yu GQ, Li C. 2018. Effects of precipitation and different distributions of grass strips on runoff and sediment in the loess convex hillslope. CATENA 162: 130-140. https://doi.org/10.1016/j. catena.2017.12.002.

\section{Supporting Information}

Additional supporting information may be found online in the Supporting Information section at the end of the article.

Data S1 Supporting Information 